Journal of Sustainability Perspectives

journal homepage: $\underline{\text { https://ejournal2.undip.ac.id/index.php/isp/ }}$

\title{
Water Management in UGM for Resilient and Healthy Campus
}

\author{
Panut Mulyono ${ }^{1,}$, Sentagi Sesotya Utami ${ }^{2}$, Budi Prayitno ${ }^{3}$, Fiki Rahmatika Salis ${ }^{4}$, Faridah ${ }^{5}$ \\ 1,2,3,4,5 Universitas Gadjah Mada, Indonesia \\ *corresponding author: pmulyono@ugm.ac.id
}

\section{Article Info}

Received:

15 March 2021

Accepted:

25 May 2021

Published:

1 August 2021

DOI:

Presented in The $6^{\text {th }}$ International (Virtual) Workshop on UI GreenMetric World University Rankings (IWGM 2020)

\begin{abstract}
Water management is one of the most challenging aspects of campus management. With a large number on campus population and limited water resources, water management is essential for achieving a resilient and healthy campus. In this paper, we explain two targets in UGM water management: water efficiency and water conservation. Both objectives are significantly related; however, each goal has a different approach to the method for the design approach and strategies in the implementations. Water efficiency is included in building new buildings and retrofitting the existing ones. Meanwhile, water conservation is implemented to calculate potential alternative water resources in UGM, including water treatment, to produce freshwater as an additional water supply. We also explain how water management is implemented in UGM from the highest Directorate to the lowest units. Through our method and best practices in UGM, we hope our paper could be a reference for other universities who want to implement a water management program.
\end{abstract}

\section{Keyword:}

Water management, water efficiency, water conservation, green campus

\section{Introduction}

The main campus layout of Universitas Gadjah Mada (UGM) in Yogyakarta, Indonesia, with a total area of 20,456,345.9 meter square is considered spread in several building complexes, connected by the province's main streets and campus roads, and crossed by a river, the Belik River. It passes certain areas with low altitude where flooding frequently happens. A large number of university population and also the diversity of the building function is one of the aspects that makes it difficult to manage. Buildings are designed as learning centers, laboratories/research centers, a hospital, to building for offices with many supporting structures for operational and maintenance. Water management, therefore, is one of the most challenging aspects of campus management. In this paper, we explain the two targets in the water management of UGM, water efficiency and water conservation. 
Both objectives are significantly related; however, each goal has a different approach to the method for the design approach and strategies in the implementations.

In the past five years, many constructions were done in UGM, where new buildings are built. The student body has also increased in the past three years with more than 50,000 students in 2019. These new buildings should be concerned due to their energy and water consumption to support the learning activities of such a large student body (more than 55.000 students). A water calculator predicts the water consumption for new buildings by calculating the amount of water needed for a building to operate. The water usage components are for fulfilling the occupants' daily activity, building operational, landscape maintenance, and fire safety system. By having made such an approach shall provide a strategical solution in the water supply system. The need for a large volume of clean water resources can be compromised by using alternative water resources other than water from the primary sources (well and district water supply).

In order to provide alternative water resources, water conservation techniques should be implemented, especially highlighting the use of potential water resources in UGM. Implementation starts from the early stage design for new buildings and revitalization for existing buildings, integrating with the landscape and other land usages. We shall share UGM's experience in water management and some methods used in the design approach of the systems implemented, both for the water efficiency and water conservation objectives.

\section{UGM's Water Management Program}

Policy related to the UGM's water management goals is implemented from the university's management level to the level of Faculty or Units management. Fig. 1 illustrates the management side's hierarchical aspects, from policy to ideas, design, and implementation. There are several teams or units in charge of the entire process with specific roles, as described as follows. The Directorate of Planning has the highest hierarchy position in planning the strategies for water management. Every construction project requires authorization, and an application system is provided by the Directorate of Planning that serves as a database system, named as 'Siresik.' Data inputted are the DED and other planning information for a new building. For an existing building, the data are the As-Built Drawing with the DED of the renovation plan and building services installed. Identifying the area of open land potential for land-surface catchments and the rainwater harvesting system's detention basin is one of the water conservation design steps. This information shall support research centers and the UGM's Green Team in recommending the best water conservation system that should be applied for a building or unit area within UGM. Recommendations are then given to the Directorate of Assets and units or faculty who are responsible for implementing the idea. The system shall be connected with the entire water management system, including the water metering system currently developed to be centrally monitored through a dashboard in the Campus Management System (CMS). 


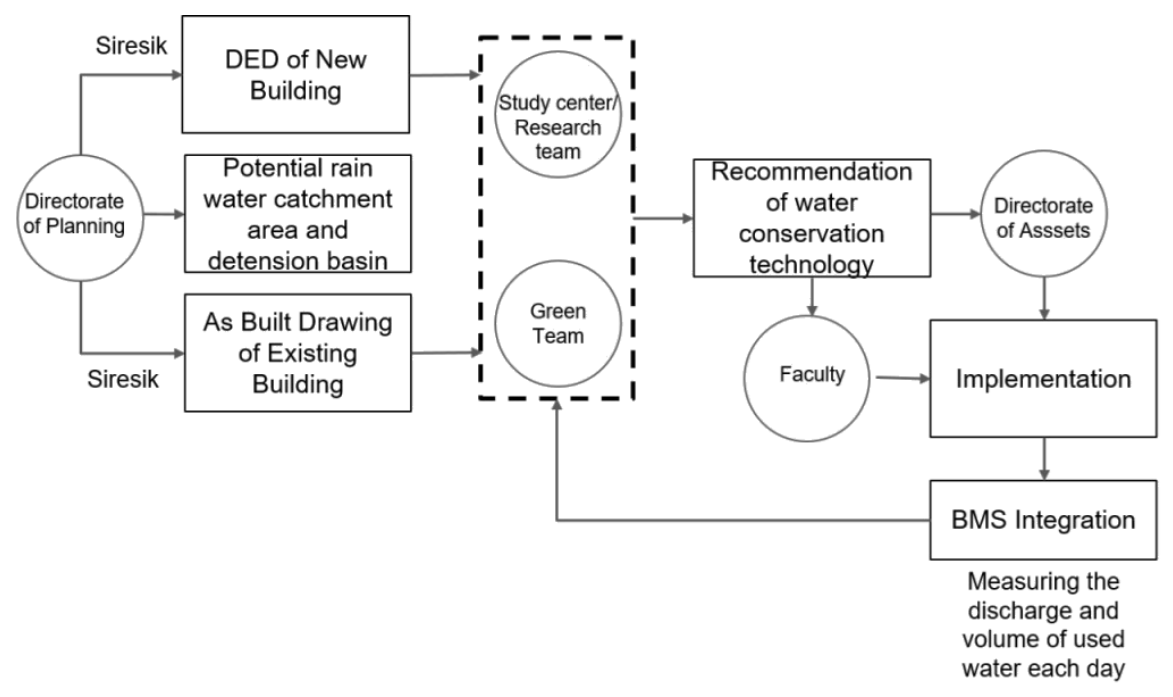

Figure 3. the management side's hierarchical aspects

\section{Method of Water Balance Calculation for New Building}

All the data related to a new building and existing building design are stored in the directorate's database system (Siresik), and also data of potential area for rainwater catching and water detention system. For the new buildings, water consumption efficiency can only be achieved if water usage is predicted by calculating the balance between demand and supply. There are some standards and calculation methods available in Indonesia. For this purpose, the green team of UGM responsible for conveying the green campus realization lead by the Integrated Smart and Green Building (Insgreeb) research group, proposed a method to predict the water balance of a building based on available methods standards. The steps for calculation are provided in Fig. 2. This method adopted several standard and rating tools available in Indonesia, one of them is the Greenship rating tools from Green Building Council in Indonesia ( $\mathrm{GBCl}$ ) using several parameters for Water Conservation (WAC) criteria. The WAC consists of several assessment parameters, which are water metering system, water usage calculation, water usage reduction, water features, water recycling program, alternative water sources, rainwater harvesting, and landscape water usage efficiency.

Building data needed in the water balance calculation are the building detailed engineering drawing (DED). Other information needed is the net lettable area (NLA) in meter square, total occupants (in person), total cooling load of the air conditioning system (in Ton Refrigerant), total landscape area, and also the building operational hours. A national standard that lists the amount of water used by each person per day for a variety of building types is available (SNI). This information for each type of water fixtures in the building design multiplied by the number of occupants gives the total amount of water per fixture. Using the diagram, we can see that the total water consumption per day per person is the total amount of water flow through the fixtures, water needed for cooling towers, and water for landscape irrigation. A building operates in its best performance if the water supply system fulfills the amount this water needed. To achieve efficiency is by reducing the amount of clean water supply from primary water sources (well or a district water supply system).

Alternative water resources should be addressed in the supply system through a water conservation program that is designed to optimize the use of on-site potential water 
resources. In a campus, these resources are owned and managed by the university, whilst located within the campus area.

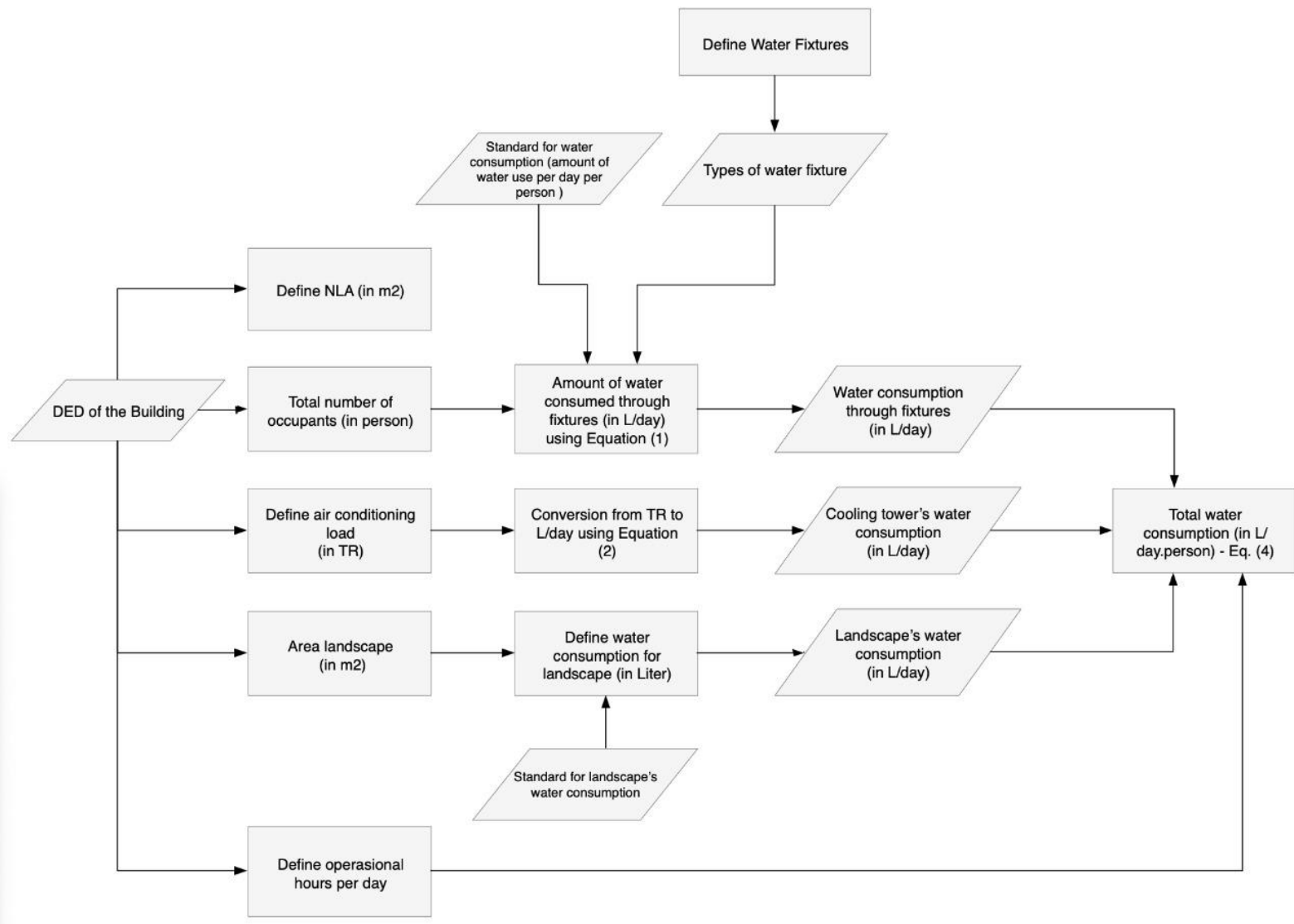

Figure 4. Method of Water Conservation in A Campus Area

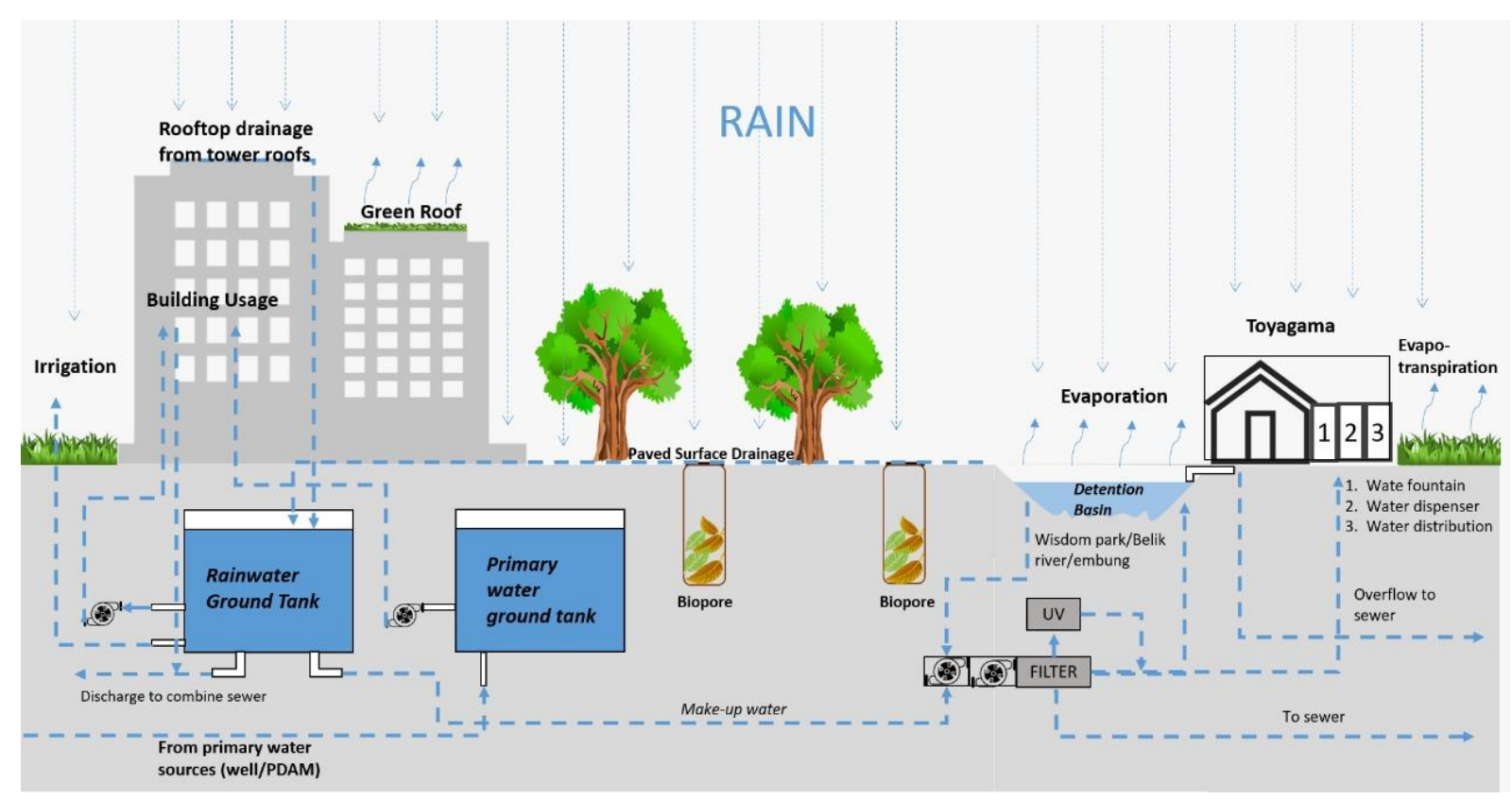

Figure 5. Water conservation program in UGM

A thorough estimation of the water usage of a building to obtain a water efficiency is already part of a water conservation program since the water supply is usually considered at 
once during the demand calculation. However, this section discusses in more detail the ability of UGM's building and landscape to provide most of the clean water using alternative resources.

Yogyakarta, the city where UGM is cited, is a city with high rainfall on average of 400 $500 \mathrm{~mm} /$ month [1]. In the dry season, the use of clean water is fully supplied by primary water resources, even for landscape irrigation purposes. The excessive use of primary water resources has become a major concern for university management due to the water consumption bills and the utility bills used for the water storage and distribution systems. Rooftops with rainwater harvesting system should be the solution to optimize rain as an alternative water resource. Therefore, in the past five years, all the new buildings in UGM are designed to have this system installed.

As mentioned above, the Directorate of Planning estimates the total potential area for surface catchments and the rainwater harvesting system's detention basin. Besides the use of rooftops with a guttering system, green roofs are now starting to be promoted in several new buildings of UGM. We are currently designing a total of 6 hectares of an integrated green roof at the central campus area. It is a challenging project that requires the support of research centers and the green team since the early stage of the architect's design process. The area for land-surface catchments is embedded with the landscape designs and pavements.

Meanwhile, the type of detention basins applied in UGM is in the form of vegetated depressions surrounding a human-made pond connected to the Belik River. This area is known as Wisdom Park, serves as a campus recreational area and public open space [2]. The area is planted with native trees in Yogyakarta and providing habitats for wildlife. A ground tank rainwater supports the detention system. Excessive water is drained out from the site through an integrated drainage system that covers the entire central campus area and ends at Wisdom Park. A stormwater drainage system also exists in the Faculty of Engineering as a part of the Technopark. Both these detention systems have a water treatment system with a technology that processes the water from this open source (at Wisdom Park) into freshwater for drinking, labeled as Toya Gama. Detail of these water conservation components is discussed further in the following sub-sections.

\section{Water Conservation Program in UGM}

\subsection{Storm-water Drainage System}

During the wet season, the rainfall can reach up to $400-500 \mathrm{~mm} / \mathrm{month}$, causing flood in low elevated areas [1]. The Belik river crosses the east side of UGM's campus area. Before the development of Wisdom Park started in 2017, this river caused a flood to the resident's area near the campus and even at several street joints that passed UGM. 


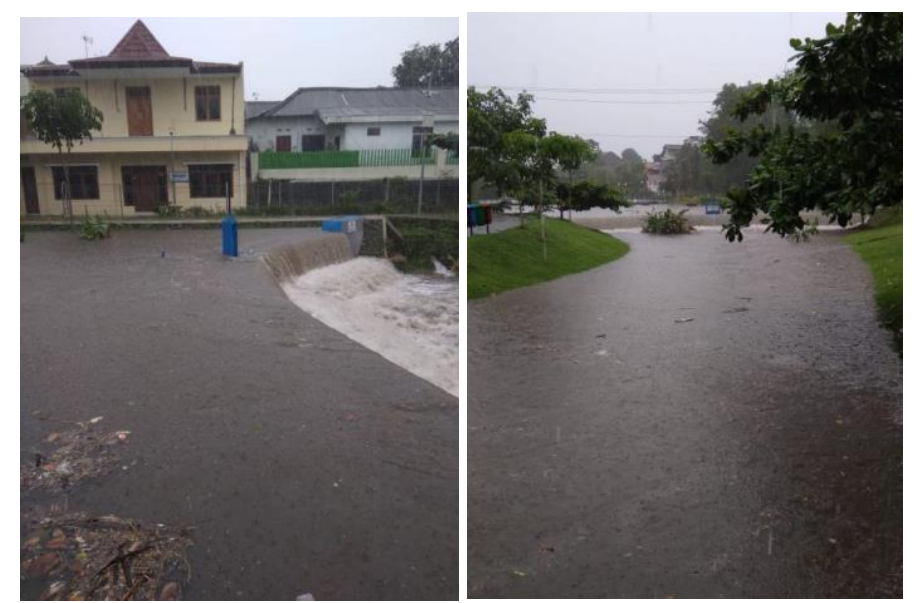

Figure 6. Storm-water drainage system in Wisdom Park UGM

Since the flood occurrence became unbearable, with the support from several industries and commercial institutions such as banking through community service research (CSR) program, UGM developed the riverbank area and turned it into a campus urban park with a sophisticated storm-water drainage system. The storm-water drainage system could accommodate 31,500 meter cubic of water; thus, the water would not cause flood and damage area in Wisdom Park UGM. Storm-water drainage system in Wisdom Park UGM can be seen in Fig. 4.

Wisdom Park also has an artificial lake to restore the function of environmental components (river, forest, etc.), to create a microclimate, and improve the air and environmental quality. Aside from Wisdom Park, UGM also established a storm-water drainage system in the Faculty of Engineering as a part of the Technopark development program in 2018 (Fig. 5) It was funded by the Indonesian Ministry of Public Work and Housing. It is also used for processing waste that comes from buildings in the faculty.

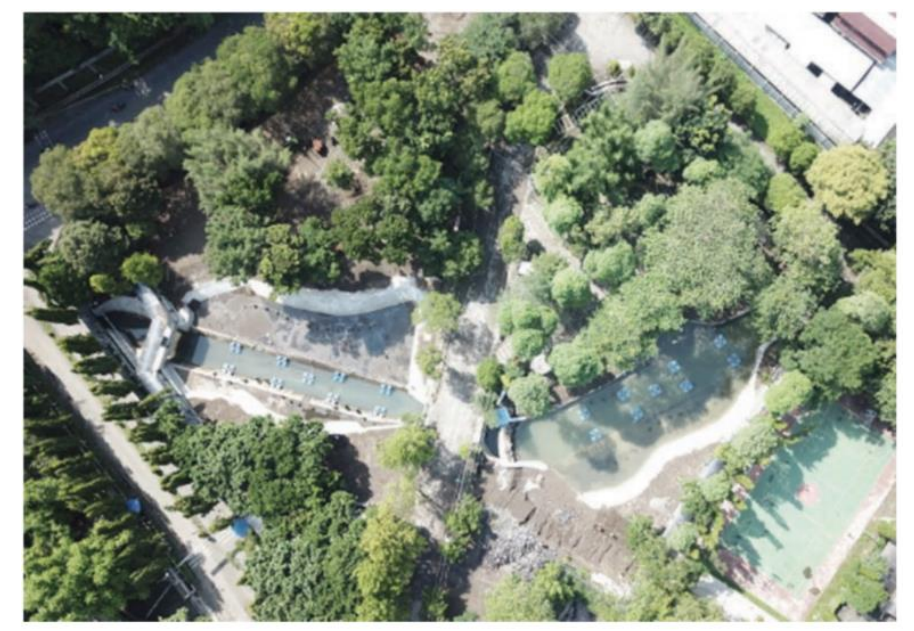

Figure 7. Storm-water drainage system in the Faculty of Engineering UGM

\subsection{Rainwater Harvesting}

Rainwater harvesting is collecting and storing rainwater for fulfilling water demand. The rainwater that flows from a building roof can be stored in a pond or tank. The utilization of rainwater is divided into potable and non-potable. Potable is the rainwater that can be consumed as drinking water after being processed, while non-potable is for non-drinking 
usages, such as toilet flush, gardening, fire extinguisher, laundry, and so on forth. The advantages of using a rainwater harvesting system are additional water supply, increasing ground humidity, additional groundwater through infiltration, flood prevention, and moneysaving for water usage. However, it requires water treatment to filter the water from animal and organic waste. The rainwater harvesting system consists of several main components, including collecting systems, storage systems, and distribution systems [3].

1. Collecting system

The collecting system is utilized to collect rainwater directly and installed in the building roof. The rainwater will flow through a channel and vertical pipe into a storage tank. The characteristic of a collecting system affects the storage tank condition. The characteristic includes a run off coefficient to calculate losses due to water spill, leakage, permeation, and evaporation. The run off coefficient (C) is the ratio between run off water volume on the roof surface and the rainfall that hits the roof surface. [skripsi hasmiati ref. No 22] The $C$ value depends on the material used for the collecting system. [skripsi hasmiati ref. No 23] Rooftop material is essential in designing a rainwater harvesting system. Several materials could produce toxicant, which can be mixed into the rainwater. Some of the recommended rooftop materials are steel, concrete tile, terracotta, zinc-coated, and zinccoated metals. Asphalt, copper, or flashing materials are not recommended due to its acidity and toxic content [4].

2. Storage system

A storage system is used for storing rainwater, which is then consumed for daily water needs. The storage system could be in the form of a tank installed on the ground or underground. Several factors that affect the tank size are rainfall rate in the location, demand, dry season period, rainwater collecting area, aesthetic factor, and construction budget. A storage tank has to be opaque to prevent algae growth, enclosed for preventing mosquito proliferation, hygiene, and not using toxic materials. Some of the recommended materials are fiberglass, polyethylene, metals such as a steel drum and zinc-coated steel tank, concrete such as ferrocement, monolithic, and concrete blocks [4].

3. Distribution system

A distribution system is used to distribute rainwater toward a storage tank, building needs, and sewerage, which consists of several subsystems, including collecting, utilizing, and disposal. The collecting system distributes rainwater from collecting area into the storage tank, in the form of channels and downspouts (vertical pipes) that connect the collecting area, storage tank, and filter. Lead screen and first-flush diverter (FFD) are filters generally used in this system. Leaf screen is utilized for filtering leaf or big-sized dirt, while FFD is for filtering dirt from collecting area. A utilization system is used for distributing rainwater from a storage tank to water appliances in the building. It could be used for drinking water, toilet flush, irrigation, fire extinguisher, etc. It consists of pipes, water pumps, and water treatment systems to increase water quality. Meanwhile, the disposal system is used to dispose of excessive rainwater when the storage tank cannot store it. It consists of pipes that connect the storage tank with the city drainage system [5].

Universitas Gadjah Mada installed both upper ground and underground rainwater harvesting systems in several faculties and areas, as shown in Fig. 6. 


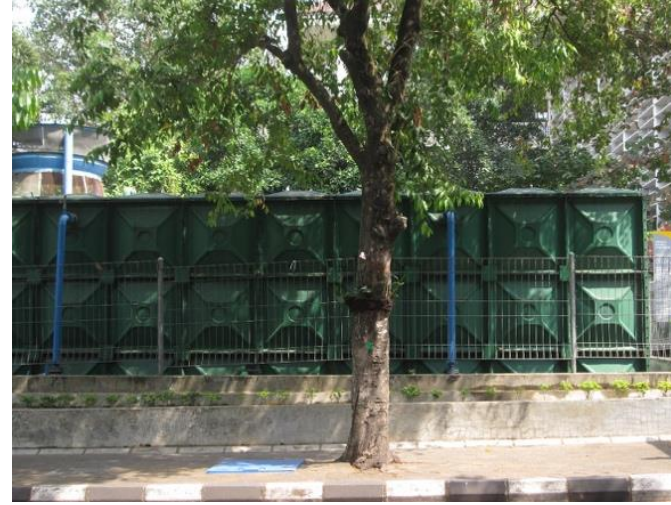

(a)

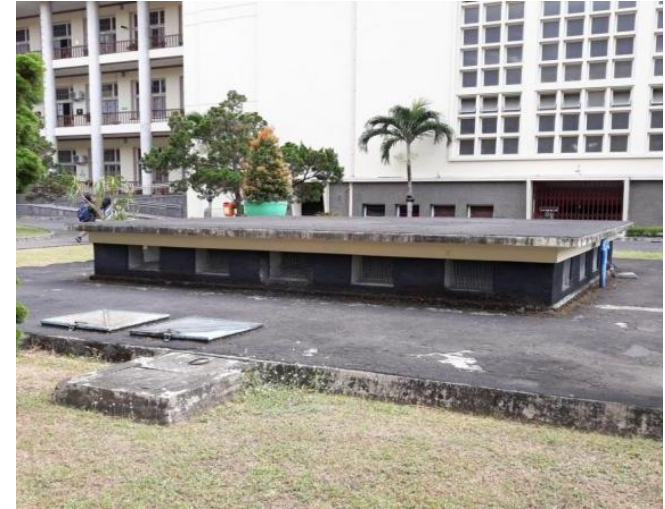

(b)

Figure 8. (a) Faculty of Medicine, Public Health and Nursing, (b) UGM's Main Office

\subsection{Grey Water}

Greywater is one of the environmental issues that cause sewerage or rivers to be dirty and smelly. Greywater could come from many activities, such as laundry, shower, washing hands, washing the dishes, etc. Universitas Gadjah Mada has many buildings, including students' dormitory, namely UGM Residence, where those activities could happen. Therefore, UGM implements a water recycle program with two methods: up-flow filtration and down-flow filtration. In up-flow filtration, a slow sand filter is used in the storage tank with a filter aggregate order consists of several layers. The first layer is $5-30 \mathrm{~mm}$ diameter gravels, the second layer is $3-4 \mathrm{~mm}$ gravels, and the last layer is $0.3-1 \mathrm{~mm}$ diameter sand. The water inlet is installed in the last layer, while the water outlet is installed above the first layer. Therefore, this system is called up-flow filtration. Meanwhile, down-flow filtration consists of the same components; however, it is installed in reverse.

\subsection{Bio-pores}

One of the water conservation strategies is bio-pores. It is an alternative and simple technology to absorb rainwater. In 2018, there were 23 bio-pores in the Faculty of Animal Science UGM with a 4-inch diameter. The Faculty of Biology also already installed bio-pores. In 2019, UGM committed to increasing the number of bio-pores in UGM area. Aside from absorbing water and preventing flood, it could also fertilize the soil, recycle organic waste, and preserving the environment. Through community service program in 2019, UGM installed bio-pores in several spots. Its functions are for natural composting tools and absorbing rainwater. The UGM's students installed 100 bio-pores in Wisdom Park, 175 biopores in Kinanti Residence, and 50 bio-pores in UGM main office area.

\section{Toya Gama}

Toya Gama is an independent water supply by Universitas Gadjah Mada for its academicians on campus, both raw water, planning, processing, and management aspects. Toya Gama plays an essential role in decreasing foreign product expansion rate in the drinking water supply and reducing UGM's academicians' dependency on foreign drinking water consumption. The raw water comes from a shallow well behind the Toya Gama building. Toya Gama water is processed through several stages to produce high qualified drinking water and tested by Toya Gama laboratory and a regional institution certified by the National Accreditation Committee; thus, its quality can be guaranteed. The testing includes several physical parameters: smell, color, total dissolved solids, viscosity, taste, 
temperature, chlorine, $\mathrm{pH}$, and conductivity. After being tested, the water will be processed through three stages: pre-treatment, ultra-filtration, and ultraviolet. Sand and carbon filters filter the raw water and collect it into a feed tank. Then, the water is called a feed-water. Feed-water is pumped by UF Feed Pump toward Automatic Cleaning Filter (ACF). After that, the water is pumped into the ultra-filtration system and ultraviolet radiation.

\subsection{Pre-Treatment}

The pre-treatment stage includes water filtering through a sand filter and a carbon filter. Those filters are installed parallel to each other. The sand filter is used to filter dirt in the water. Dirt in the form of colloid will be detained in the form of gelatin, while quartz sand's ions will neutralize ions in water. Besides, the sand's zoogleal layer containing living organisms will eat organic material and clean the water. Therefore, a quartz sand filter can work as a mechanic, electrolysis, and bactericidal filter. After being filtered, the water is collected into a feed tank; thus, it is called feed-water.

\subsection{Ultra-filtration}

In the ultra-filtration stage, feed-water is filtered by a tiny filter (until nanoscale). The ultra-filtration system is similar to the human kidney function. After being filtered, the water is then pumped towards ultraviolet radiation.

\subsection{Ultraviolet}

Feed-water from the ultra-filtration stage is scanned using ultraviolet waves to kill the bacteria and virus. After going through this process, the water is ready to be drinking water and collected into a drink tank to be distributed in the UGM area later.

Toya Gama provides three types of service, including 50 units of water fountain, 12 units of water dispenser, and 25 units of a housing water distribution. Those facilities are installed and connected to all faculties and buildings in the UGM area.

- Water fountain

Toya Gama has 50 units of water fountain installed in all faculties and buildings in the UGM area. This facility provides free drinking water for all people. The water fountain's maintenance is conducted once in a week by Toya Gama to maintain its hygiene. Water fountains could provide healthy and environmentally friendly drinking water. It can reduce plastic bottled water consumption. Therefore, the water fountain is one of UGM's contributions to preserve the environment.

- Water dispenser

The water dispenser is a public facility by Toya Gama that provides cold, warm, and hot water. It aims to give convenience for UGM's academicians and people in obtaining all types of drinking water for free. The water dispensers are installed in several buildings in the UGM's area. It is also disability friendly because the buttons contain braille.

- Housing water distribution

Toya Gama also provides drinking water distribution for houses inside UGM's area. Those are UGM official residences, and Toya Gama already installed 25 units. This water distribution system has a water metering system to measure water consumption in each house. By providing drinking water to houses, this facility aims to reduce energy consumption, especially electricity and gas usage. 


\section{Summary/ Concluding Remarks}

Standards, policy, and best practices for campus water management that have been proven successfully implemented are available in many universities throughout the world. Remarkable results in water efficiency and water conservation programs are only possible if the water management program considered the potential resources and technical obstacles during the implementation. Good governance is also required, which involves expertise in water conservation and all related units within the university. These challenges are uniquely different for each university. Therefore, we hope the ideas we have shared from UGM can be lessons learned for other universities and provide us the opportunity to gain feedback for better improvement toward achieving our campus development goal, 'UGM as a Resilient and Healthy Campus.

\section{References}

1. BMKG DIY, 2017. BMKG DIY : Inilah Puncak Musim Hujan di Jogja. Available online at: https://jogya.com/bmkg-diy-inilah-puncak-musim-hujan-di-jogja-2/, accessed on 8, July, 2020.

2. Natural Water Retention Measures, 2014. Individual NWRM Detention Basins. Available online at http://nwrm.eu/measure/detention-basins, accessed on 8, July, 2020.

3. Irsan V., Atika L., Edi, R., 2012. Potensi Rainwater Harvesting Dalam Upaya Mengurangi Limpasan Permukaan Menggunakan Model HEC-HMS. Institut Teknologi Bandung, Indonesia.

4. 2012. Residential Rainwater Harvesting Design and Installation. Regional District of Nanaimo, British Columbia.

5. Sentagi S.U., 2014. Green Technology II. Building Physics Course, Department of Nuclear Engineering and Engineering Physics, Faculty of Engineering, Universitas Gadjah Mada, Yogyakarta, Indonesia. 